\title{
Crystal Structure of [Dihydrido-hexaphenylcarbodiphosphoran][chlorid]- [trichlorido-triphenylphosphino-platinat]
}

\author{
Wolfgang PetZ Pa Bernhard NeumülleR $^{\dagger}$ \\ Department of Chemistry, Philipps University of Marburg, Hans-Meerwein Str. 4., D-35032 Marburg, Germany
}

\begin{abstract}
The crystal structure of the salt [dihydrido-hexaphenylcarbodiphosphoran][chlorid][trichlorido-triphenylphosphinoplatinat] was determined by X-ray crystallography. The title compound crystallizes in the monoclinic space group with the cell parameters $a=38.858(3) \AA, b=10.851(1) \AA, c=27.666(2) \AA, \alpha=90^{\circ}, \beta=109.07(1)^{\circ}, \gamma=90^{\circ}, V=11025(2) \AA^{3}$, $Z=8$. The crystal structure was solved by direct methods and refined by full-matrix least-squares on $F^{2}$ to final values of $R 1=0.0771$ and $w R 2$ (all data) $=0.1732, T=100(2) \mathrm{K}$.
\end{abstract}

(Received December 20, 2020; Accepted March 15, 2021; Published on web July 10, 2021)

The title compound (Fig 1) was obtained in minor amounts upon attempts to synthesize a cationic platinum olefin complex by reacting the dicationic olefin complex $\left[\left(\mathrm{PPh}_{3}\right)_{2} \mathrm{C}=\mathrm{CH}_{2}\right] \mathrm{Br}_{2}{ }^{1}$ (an addition product of the carbone $\mathrm{C}\left(\mathrm{PPh}_{3}\right)_{2}$ at the four electron species $\mathrm{CH}_{2}{ }^{2+}$ ) with $\mathrm{PtI}_{2}$ (cod) in DCM solution. No spontaneous reaction sets in. After one day of standing at room temperature, orange crystals separated. A complex reaction occurred and the ${ }^{31} \mathrm{P}$ NMR spectrum of the solution exhibits 6 signals from which the signal at 19.6, 25.7 and $28.4 \mathrm{ppm}$ could be assigned to the dication $\left[\mathrm{H}_{2} \mathrm{C}\left(\mathrm{PPh}_{3}\right)_{2}\right]^{2+},\left[\left(\mathrm{PPh}_{3}\right)_{2} \mathrm{C}=\mathrm{CH}_{2}\right]^{2+}$ (starting material), and the anion $\left[\mathrm{Cl}_{3} \mathrm{Pt}\left(\mathrm{PPh}_{3}\right)\right]^{-}$, respectively. Further signals at 30.6, 38.4, and $39.9 \mathrm{ppm}$ could not be assigned so far. The unexpected formation of the salt can only be explained by the participation of the solvent $\mathrm{CH}_{2} \mathrm{Cl}_{2}$. Finally, this leads to a total exchange of the halogen molecules of the starting materials by chloride. Concerning that the chemistry of $\left[\left(\mathrm{PPh}_{3}\right)_{2} \mathrm{C}=\mathrm{CH}_{2}\right] \mathrm{Br}_{2}$ only provides little information, the above reaction was one of the first attempts to shed light on it. The splitting off $\mathrm{PPh}_{3}$ from the cation to form the $\mathrm{PPh}_{3}$ and platinum containing anion is an important hint for further studies.

Pale-yellow plate crystals of the title compound where obtained from THF/pentane. The structure was solved by direct methods and refined with the SHELX crystallographic software package. The hydrogen atoms were placed at calculated positions and refined with common displacement parameters The molecular structures are shown in Fig. 2, and the crystal

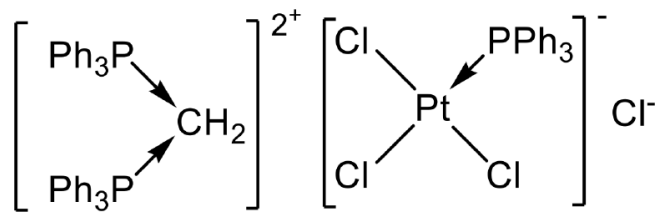

Fig. 1 Chemical diagram of the title compound.

† To whom correspondence should be addressed. E-mail: petz@staff.uni-marburg.de (W. P.); neumuell@ chemie. uni-marburg.de (B. N.) data are summarized in Table 1. The crystals were rather small and there was a weak diffraction behavior. Therefore, the ratio of the reflections $(>4 \sigma)$ /parameters was about 0.5 for a full refinement of the carbon atoms. With our used technique concerning the displacement parameters, we could perform an anisotropic refinement for all carbon atoms.

The cell contains a heavily disordered THF molecule: therefore, the SQUEEZE function of PLATON ${ }^{4}$ was applied. The SQUEEZE procedure omitted about $15.0 \mathrm{e} / \mathrm{pm}^{3} \cdot 10^{-6}$. These remaining electron densities could be assembled to two strongly disordered THF molecules: one of them with an occupation parameter of 1.0 and the other with an occupation parameter of

Table 1 Crystal and experimental data

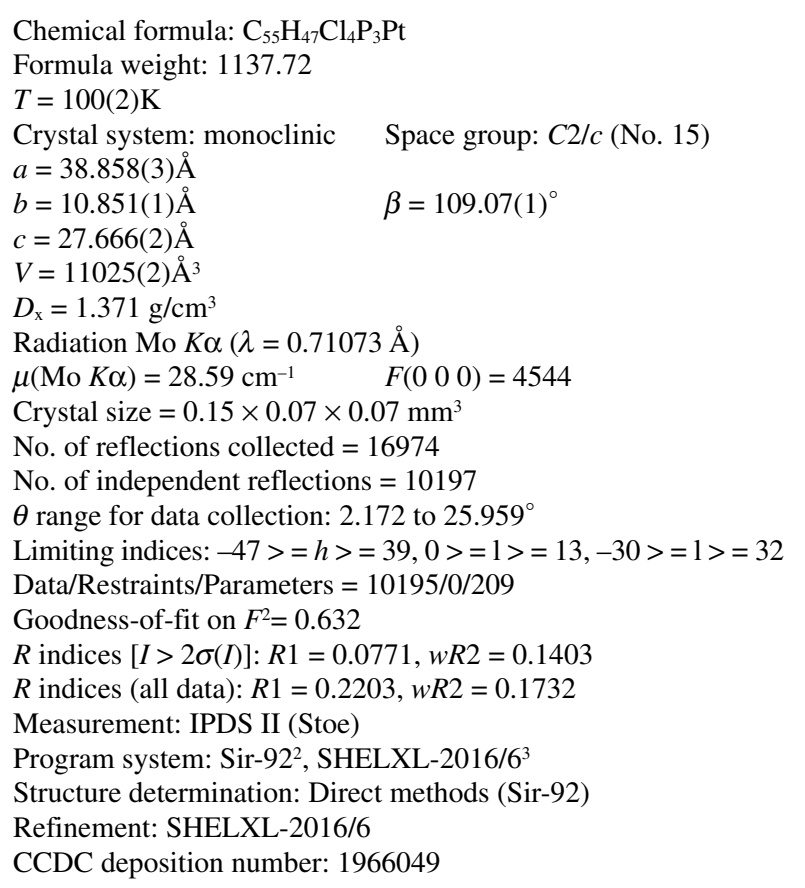




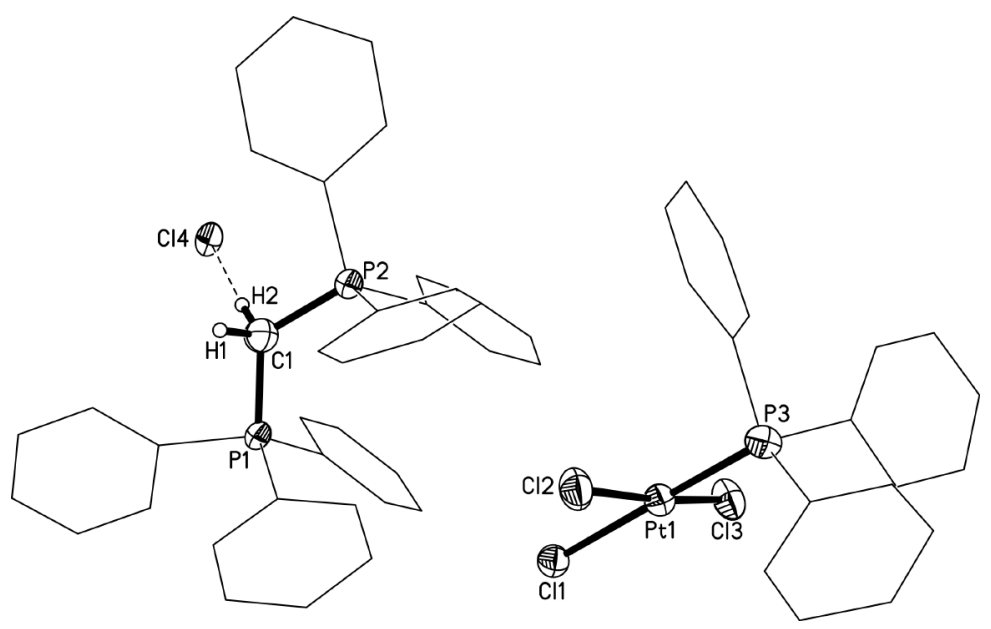

Fig. 2 Partial ORTEP drawing of the title compound, showing thermal ellipsoids at the $40 \%$ probability level. Hydrogen atoms are omitted for clarity.

Table 2 Selected bond distances $(\AA)$ and angles $\left({ }^{\circ}\right)$ in $\left[\mathrm{Cl}_{3} \mathrm{PtPPh}_{3}\right]^{-}$

\begin{tabular}{lrlr}
\hline Pt-Cl1 & $2.366(4)$ & Pt-Cl2 & $2.313(5)$ \\
Pt-Cl3 & $2.291(5)$ & Pt-P3 & $2.222(5)$ \\
P3-Pt-Cl1 & $177.4(2)$ & Cl3-Pt1-Cl2 & $174.1(2)$ \\
P3-Pt1-Cl3 & $93.2(2)$ & P3-Pt1-Cl2 & $88.5(2)$ \\
Cl3-Pt1-Cl1 & $89.2(2)$ & Cl2-Pt1-Cl1 & $89.3(2)$ \\
\hline
\end{tabular}

0.5. The center of the void is localized at 0.069610 .28765 0.20244 .

A series of compounds with the dication $\left[\mathrm{H}_{2} \mathrm{C}\left(\mathrm{PPh}_{3}\right)_{2}\right]^{2+}$ are described in the literature, which exclusively forms upon proton abstraction from the solvent $\mathrm{CH}_{2} \mathrm{Cl}_{2}$ by the carbone $\mathrm{C}\left(\mathrm{PPh}_{3}\right)_{2}$ and an appropriate Lewis acid. As anions acted $\left[\mathrm{BeCl}_{4}\right]^{2-5}$, $2 \mathrm{Cl}^{-},{ }^{6} 2\left[\mathrm{InCl}_{4}\right]^{-},{ }^{7}$ and $\left[\mathrm{AlCl}_{4}\right]^{-} / \mathrm{Br}^{-}{ }^{8}$ the $\left[\mathrm{FeCl}_{4}\right]^{-}$salt was obtained upon reacting $\mathrm{FeCl}_{3}$ with $\mathrm{PPh}_{3}$ in $\mathrm{CHCl}_{3} .{ }^{9}$ The yields range between quantitative and minor amounts. With $\mathrm{Cl}^{-}$and $\left[\mathrm{Cl}_{3} \mathrm{PtPPh}_{3}\right]^{-}$the title compound contains two different anions, the latter of which has not been structurally characterized so far. For a comparison, the structures of neutral $\mathrm{Pt}(\mathrm{II})$ complexes with a $\mathrm{Cl}_{2} \mathrm{Pt}($ Olefin $) \mathrm{PPh}_{3}$ core can be pulled up. ${ }^{10}$ The only compound with a similar $\mathrm{Cl}_{3} \mathrm{PtPPh}_{3}$ arrangement, as in the anion of the title complex, is found in trans-bis $\left(\mu_{2}\right.$-chloro)-dichlorobistriphenylphosphine)-di-platinum(II) mentioned in a review. ${ }^{11}$

The parameters of the dication $\left[\mathrm{H}_{2} \mathrm{C}\left(\mathrm{PPh}_{3}\right)_{2}\right]^{2+}$ exhibit no special characteristics relative to those previously reported (see Supporting Information, Table S2). Close contacts to the chloride ion and one of the protons of the dication exist $(\mathrm{C} 1-\mathrm{H} 2$

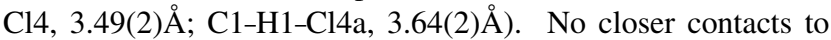
the second platinum containing anion are found. Table 2 contains selected parameters of the complex anion. The $\mathrm{Pt}(\mathrm{II})$ atom is in a planar-four coordinate environment; the sum of the angles at $\mathrm{Pt}$ amounts to $360.2^{\circ}$. All of $\mathrm{Pt}-\mathrm{Cl}$ distances are different (Pt-Cl1 2.366(4), Pt-Cl2 2.313(5), Pt-Cl3 2.291(5) А̊), and the longest one belongs to Cl1 opposite to the $\mathrm{PPh}_{3}$ group. Similar values were recorded for the olefin complexes. ${ }^{10}$ The title compound exhibits a remarkable short Pt-P bond length of 2.222(5)A, while the related bond lengths in the olefin complexes are longer (2.2610(7) and 2.2517(8) $\mathrm{A}) .{ }^{10}$
Several further compounds with the structural motif $\mathrm{Cl}_{3} \mathrm{PtPPh}_{3}$ but with $\mathrm{Pt}(\mathrm{IV})$ and the platinum atom in an octahedral environment are found in the literature. These compounds exhibit similar $\mathrm{Pt}-\mathrm{Cl}$, but appreciably longer Pt-P bond lengths; a mean value of $2.326 \AA$ from nine compounds was recorded. The latest publication in this field stems from Amico et al., including earlier reports. ${ }^{12}$

\section{Supporting Information}

A CIF format file, Tables S1 and S2, Figs. S1 and S2. These materials are available free of charge on the Web at http://www. jsac.or.jp/xraystruct/.

\section{References}

1. M. A. Celik, G. Frenking, B. Neumüller, and W. Petz, ChemPlusChem, 2013, 78, 1024.

2. A. Altomare, G. Cascarano, C. Giacovazzo, A. Guagliardi, M. C. Burla, G. Polidori, and M. Camalli, Sir-92, Rome, 1992.

3. G. M. Sheldrick, SHELXL-2016/6, Program for the Refinement of Crystal Structures, University of Goettingen, 2016, Goettingen, Germany.

4. A. L. Spek, PLATON-2014, 2014, Utrecht, The Netherlands.

5. W. Petz, K. Dehnicke, and B. Neumüller, Z. Allg. Anorg. Chem., 2011, 637, 1761.

6. W. Petz, K. Dehnicke, N. Holzmann, G. Frenking, and B. Neumüller, Z. Allg. Anorg. Chem., 2011, 637, 1702.

7. W. Petz, M. Fahlbusch, E. Gromm, and B. Neumüller, $Z$. Anorg. Allg. Chem., 2008, 634, 682.

8. W. Petz and B. Neumüller, Z. Allg. Anorg. Chem., 2013, 639, 2331.

9. J. D. Walker and R. Poli, Polyhedron, 1989, 8, 1293.

10. R. Pryadun, D. Sukumaran, R. Bogadi, and J. D. Atwood, J. Am. Chem. Soc., 2004, 126, 12414.

11. R. S. Pryadun, O. O. Gerlits, and J. D. Atwood, J. Coord. Chem., 2006, 59, 85.

12. D. B. D. Amico, D. Fioco, L. Labella, F. Marchetti, and S. Samaritani, Polyhedron, 2018, 145, 63. 